\title{
Perencanaan tata hijau jalan berdasarkan fungsi jalan di Kota Denpasar
}

\author{
l'in Lathifatus Sun'iyyah ${ }^{1}$, I Made Sukewijaya ${ }^{2 *}$, Ni Wayan Febriana Utami ${ }^{1}$ \\ 1. Program Studi Arsitektur Pertamanan, Fakultas Pertanian, Universitas Udayana \\ 2. Program Studi Agroekoteknologi, Fakultas Pertanian, Universitas Udayana \\ *E-mail: madesukewijaya@unud.ac.id
}

\begin{abstract}
The planning of green street system in Denpasar City based on street function. Denpasar city is the capital of Bali Province which is currently experiencing growth and development, one of them is street accretion in length and improvement which is continue to grow every year. Based on street function, Denpasar has three street type e.g. arterial street, collectoral street and local street. Each street has different functions and criteria that require different green street system as well as having to adjust the function and criteria of the street. The purpose of this study was to plan a green street system in accordance with the existing street function in Denpasar. Method used in this research were observation and literature study. The concept applied was the green street system aligned with functional plants. Research showed that the concept of the street was improved by implementing collaboration of between space and green concept. The findings of this research was the planning of green street system based on street function which was adjusted to the condition of its surrounding area.
\end{abstract}

Keywords: Denpasar city, green street system, street function, streetscape planning

\section{Pendahuluan}

Kota Denpasar merupakan ibukota Provinsi Bali yang saat ini mengalami pertumbuhan dan perkembangan yang pesat. Penambahan panjang jalan di Kota Denpasar meningkat 0,3\% dan perbaikan kondisi jalan meningkat 8,3\% dari tahun sebelumnya (BPS Kota Denpasar, 2012). Total panjang jalan di Kota Denpasar saat ini yaitu 576.394.000 m dengan 56\% kondisi jalannya baik (DPU, 2015). Berdasarkan fungsinya, jalan di Kota Denpasar tergolong menjadi jalan arteri, jalan kolektor, jalan lokal, dan lingkungan.

Sesuai dengan fungsi jalan, lansekap jalan sendiri terbagi menjadi tiga yaitu lansekap jalan arteri, lansekap jalan kolektor, dan lansekap jalan lokal. Jalan Cokroaminoto merupakan jalan arteri, Jalan Gunung Agung merupakan jalan kolektor, dan Jalan Serma Made Pil merupakan jalan lokal. Ketiga jalan tersebut memiliki fungsi dan kriteria yang berbeda sehingga perlu adanya perencanaan tata hijau jalan yang berbeda pula.

Rumusan masalah yang diangkat adalah bagaimana karakter lansekap Jalan Cokroaminoto, Gunung Agung, dan Serma Made Pil serta bagaimana konsep dasar serta konsep pengembangan yang akan diaplikasikan pada perencanaan tata hijau Jalan Cokroaminoto, Gunung Agung, dan Serma Made Pil.

\section{Metode Penelitian}

\subsection{Tempat dan Waktu Penelitian}

Penelitian dilakukan di Kota Denpasar pada tiga jalan yang memiliki fungsi berbeda yaitu Jalan Cokroaminoto sebagai jalan arteri Jalan Gunung Agung Sebagai jalan kolektor, dan Jalan Serma Made Pil sebagai jalan lokal. Penelitian dilakukan selama sembilan bulan, pada bulan November 2016 hingga bulan Agustus 2017.

\subsection{Bahan dan Alat}

Bahan dan alat yang digunakan dalam penelitian ini adalah alat tulis, kamera, hand phone dengan bantuan aplikasi Sound Meter untuk mengukur kebisingan, komputer dengan bantuan internet, software Microsoft Word dan Microsoft Excel Untuk mengolah data serta software AutoCAD, ArcMap, dan Adobe Photoshop untuk mengolah gambar. 


\subsection{Metode Pengumpulan Data}

Metode pengumpulan data yang digunakan dalam penelitian ini adalah observasi dan studi kepustakaan.

\subsection{Jenis Data}

Jenis data yang digunakan dalam penelitian ini terdiri dari jenis data primer yang dikumpulkan dengan metode observasi serta data sekunder yang dikumpulkan dengan metode studi kepustakaan.

\subsection{Metode Penelitian}

Metode penelitian yang digunakan mengacu pada metode proses berpikir lengkap Rachman (1984) dalam Norma et al., (2013) yang terdiri dari tahap inventarisasi, analisis, sintesis, konsep, dan perencanaan.

Analisis kepadatan lalu lintas mengacu pada kriteria tingkat pelayanan jalan dan karakteristik arus lalu lintas sebagai berikut:

Tabel 1. Kelas tingkat pelayanan jalan dan kriteria arus lalu lintas

\begin{tabular}{|c|c|c|c|}
\hline No. & Kelas Tingkat Pelayanan & Nilai V/C Ratio & Karakteristik Arus Lalu lintas \\
\hline 1. & A (sangat baik) & $<0,6$ & $\begin{array}{l}\text { a. Arus lalu lintas bebas } \\
\text { b. Volume lalu lintas rendah } \\
\text { c. Kecepatan tinggi, pemakai dapat memilih } \\
\text { kecepatan yang dikehendaki }\end{array}$ \\
\hline 2. & B (baik) & $0,6-0,7$ & $\begin{array}{l}\text { a. Arus lalu lintas stabil } \\
\text { b. Kecepatan sedikit terbatas karena } \\
\text { peningkatan volume lalu lintas }\end{array}$ \\
\hline 3. & C (sedang) & $0,7-0,8$ & $\begin{array}{l}\text { a. Arus lalu lintas stabil } \\
\text { b. Kecepatan di kontrol oleh volume lalu } \\
\text { lintas }\end{array}$ \\
\hline 4. & D (buruk) & $0,8-0,9$ & $\begin{array}{l}\text { a. Arus lalu lintas tidak stabil } \\
\text { b. Kecepatan rendah }\end{array}$ \\
\hline 5. & E (sangat buruk) & $0,9-1,0$ & $\begin{array}{l}\text { a. Arus lalu lintas tidak stabil } \\
\text { b. Kecepatan rendah } \\
\text { c. Volume lalu lintas mendekati kapasitas }\end{array}$ \\
\hline 6. & F (sangat buruk sekali) & $>1,0$ & $\begin{array}{l}\text { a. Arus lalu lintas sangat terhambat } \\
\text { b. Kecepatan sangat rendah, banyak } \\
\text { kendaraan berhenti } \\
\text { c. Volume lalu lintas di atas kapasitas }\end{array}$ \\
\hline
\end{tabular}

Sumber: Direktorat Bina Jalan Kota, 1997

\subsection{Batasan Penelitian}

Penelitian dilakukan di Jalan Cokroaminoto, Jalan Gunung Agung, dan Jalan Serma Made Pil. Penelitian dilakukan hingga tahap perencanaan yang menghasilkan site plan.

\section{Hasil dan Pembahasan}

\subsection{Kondisi Umum Kota Denpasar}

Secara geografis Kota Denpasar berada antara $08^{\circ} 35^{\prime} 31^{\prime \prime}-08^{\circ} 44^{\prime} 49^{\prime \prime}$ lintang selatan dan $115^{\circ} 10^{\prime}$ $23^{\prime \prime}-115^{\circ} 16^{\prime} 27^{\prime \prime}$ bujur timur. Kota Denpasar memiliki luas wilayah $12.778 \mathrm{Ha}$ yang terdiri dari $2.479 \mathrm{Ha}$ sawah, $510 \mathrm{Ha}$ pertanian bukan sawah, dan sisanya 9.789 Ha lahan bukan pertanian seperti jalan, permukiman, perkantoran, sungai dan lain-lain (BPS Kota Denpasar, 2012). Kota Denpasar berada pada ketinggian $0-75 \mathrm{~m}$ dpl. Kemiringan lerengnya berkisar $0-8 \%$. Jenis tanahnya latosol cokelat kekuningan dan aluvial (Pemerintah Daerah Kota Denpasar, 2015). 


\subsection{Inventarisasi}

3.2.1 Aspek Biofisik

1. Lokasi

Penelitian dilakukan di tiga fungsi jalan yaitu Jalan Cokroaminoto yang merupakan jalan arteri terletak di Kecamatan Denpasar Utara yang berjarak $1.700 \mathrm{~m}$ dari pusat Kota Denpasar dan panjang ruas jalan yang digunakan adalah $1.500 \mathrm{~m}$ (31\% dari panjang total ruas Jalan Cokroaminoto), Jalan Gunung Agung yang merupakan jalan kolektor terletak di Kecamatan Denpasar Barat yang berjarak $1.900 \mathrm{~m}$ dari pusat Kota Denpasar dan panjang ruas jalan yang digunakan adalah $1.500 \mathrm{~m}$ (45\% dari panjang total ruas Jalan Gunung Agung), dan Jalan Serma Made Pil yang merupakan jalan lokal terletak di Kecamatan Denpasar Barat yang berjarak $2.000 \mathrm{~m}$ dari pusat Kota Denpasar dan panjang ruas jalannya yaitu $630 \mathrm{~m}$ (100\% dari panjang total ruas Jalan Serma Made Pil).

2. Topografi Tapak

Jalan Cokroaminoto berada pada ketinggian 31,4 - 45, $8 \mathrm{~m}$ dpl, kondisi jalan cenderung datar dan lurus serta terdapat tikungan setelah Gang Jelantik. Jalan Gunung Agung berada pada ketinggian 26,5 - 34 $\mathrm{m}$ dpl, kondisi jalan cenderung lurus dan sedikit bergelombang pada antara Gang Gangga dan Yamuna hingga perempatan Jalan Buluh Indah dan Mahendradatta. Jalan Serma Made Pil berada pada Ketinggian 17,7 - 21,5 $\mathrm{m}$ dpl, kondisi jalanya cenderung datar dan lurus.

3. IKlim

Suhu udara rata-rata Kota Denpasar selama 10 tahun dari tahun $2007-2016$ adalah $27,7^{\circ} \mathrm{C}$ dengan kelembaban udara rata-rata 77\% (BPS Kota Denpasar, 2007 - 2016).

4. Kebisingan

Pada Jalan Cokroaminoto tingkat kebisingan di area perdagangan dan jasa $64,4 \mathrm{~dB}$, area pendidikan $63,2 \mathrm{~dB}$, area kesehatan $60,6 \mathrm{~dB}$, dan area terminal 61,2 dB. Tingkat kebisingan Jalan Gunung Agung pada area perdagangan dan jasa adalah $66,5 \mathrm{~dB}$ serta pada area pendidikan $63,2 \mathrm{~dB}$. Sementara tingakat kebisingan pada Jalan Serma Made Pil yaitu 62,9 dB pada area perdagangan dan jasa serta 57,1 dB pada area pendidikan.

5. Vegetasi

Terdapat 136 jenis vegetasi pada tapak penelitian. Terdapat 113 jenis vegetasi pada Jalan Cokroaminoto, 79 jenis pada Jalan Gunung Agung, dan 62 jenis vegetasi pada Jalan Serma Made Pil.

Beberapa permasalahan yang terjadi pada jalur penanaman antara lain jenis vegetasi yang tidak cocok digunakan sebagai tanaman jalan, jalur penanaman yang ditumbuhi gulma, jalur penanaman gersang, jalur tanaman ditutupi perkerasan (plesteran), dan jalur tanaman yang terbengkalai hinga dijadikan tempat pembuangan sampah serta penggunaan tanaman jenis pohon pada jalan lokal Serma Made Pil yang menimbulkan kesan sempit.

\subsubsection{Aspek Sosial}

Berdasarkan Peta Rencana Pola Ruang Wilayah Kota Denpasar Tahun 2011 - 2030, sepanjang Jalan Cokroaminoto terdiri dari area perdagangan dan jasa, pendidikan, kesehatan, dan terminal. Volume lalu lintas harian rata-rata Jalan Cokroaminoto adalah 2.081,25 smp/jam. Sepanjang Jalan Gunung Agung terdiri dari area perdagangan dan jasa serta area pendidikan. Volume lalu lintas harian rata-rata Jalan Gunung Agung adalah 1.209,9 smpljam (Dishub Kota Denpasar, 2015). Sepanjang Jalan Serma Made Pil terdiri dari area perdagangan dan jasa serta area pendidikan. Berdasarkan hasil observasi, volume lalu lintas harian rata-rata Jalan Serma Made Pil adalah 889,8 smp/jam.

\subsection{Analisis dan Sintesisi}

\subsubsection{Aspek Biofisik}

1. Lokasi

Jarak lokasi penelitian dengan pusat Kota Denpasar yang cukup dekat merupakan potensi yang bisa dikembangkan dengan memanfaatkan jalur hijau sebagai identitas kota dengan penggunaan tanaman Jempiring (Gardenia jasminiodes) yang merupakan maskot Kota Denpasar sebagai salah satu tanaman jalan. 2. Topografi Tapak

Secara umum kondisi topografi pada tapak penelitian cenderung datar dan lurus. Hal ini merupakan kendala karena mampu menimbulkan kesan monoton yang mana akan memicu kebosanan bagi pengguna 
jalan. Menurut McClusky dan Subadyo (2003) dalam Bararatin dan Hayati (2016), kemonotonan pada jalan dapat diminimalisir dengan penanaman tanaman dengan komposisi yang beragam. Sehingga pada perencanaan tata hijau jalan tersebut di gunakan tanaman jenis pohon, perdu, dan semak.

3. Iklim

Berdasarkan suhu udara rata-rata selama 10 tahun $27,7^{\circ} \mathrm{C}$ dan kelembaban udara rata-rata $77 \%$, maka nilai THI Kota Denpasar adalah 26,4. Nilai THI Kota Denpasar masih tergolong nyaman tapi suhu udara di tapak penelitian pada siang hari terasa panas karena kurannya vegetasi. Akbari (2002) dalam Walidaen (2017) mengungkapkan bahwa naungan pohon mampu memblokir radiasi matahari yang diterima permukaan sehingga mengurangi temperature permukaan sekitar. Sehingga penambahan vegetasi pada tapak penelitian sangat diperlukan untuk menurunkan suhu permukaan sekitar tapak penelitian.

4. Kebisingan

Tingkat kebisingan pada area pendidikan dan kesehatan pada tapak penelitian sudah melebihi baku kebisingan sehingga sudah tergolong tidak nyaman. Kebisingan dapat berpengaruh pada kesehatan indra pendengar, mempengaruhi gangguan fisiologi dan psikologis pada masyarakat.

Grey dan Deneke (1986) dalam Iman (2016) menyatakan bahwa tanaman mampu meredam suara dengan cara mengabsorsi gelombang suara oleh daun, cabang, dan ranting. Sehingga untuk meredam kebisingan pada area pendidikan dan kesehatan di tapak penelitian sanggat perlu ditanami tanaman yang mampu meredam kebisingan.

5. Vegetasi

Pemilihan jenis tanaman pada lokasi penelitian didasarkan pada fungsi jalan, fungsi tanaman, lingkungan sekitar jalan, dan syarat penempatannya, hal ini sesuai dengan ketentuan pemilihan jenis tanaman pada Tata Cara Perencanaan Teknik Lansekap Jalan yang dikeluarkan oleh Direktorat Jenderal Bina Marga Tahun 1996.

Penanaman tanaman pada area persimpangan tidak boleh menghalangi pandangan pengemudi dan rambu-rambu lalu lintas sehingga pada area jarak pandang persimpangan digunakan tanaman dengan tinggi kurang dari 0,5 m. Penggunaan tanaman Lee Kwan Yew (Tarlmounia elliptica) pada pulau lalu lintas di Jalan Cokroaminoto tetap dipertahankan karena tanaman ini memiliki nilai keindahan dengan pola pertumbuhan yang menjuntai serta pola pertumbuhannya yang menjuntai ini tidak menghalangi pandangan pengemudi sehingga cocok untuk ditanam di pulau lalu lintas.

Mengoptimalkan pemanfaatan jalur penanaman sebagaimana mestiya merupakan solusi dari permasalahan yang saat ini terjadi pada jalur penanaman untuk menghindari pertumbuhan gulma serta pengalihfungsian jalur penanaman sebagai tempat pembuangan sampah.

\subsubsection{Aspek Sosial}

Berdasarkan hasil analisis kepadatan lalu lintas, pada Jalan Cokroaminoto tingkat pelayanannya masuk dalam kategori $\mathrm{D}$ (buruk), pada Jalan Gunung Agung masuk dalam kategori A (sangat baik), dan pada Jalan Serma Made Pil masuk dalam kategori A (sangat baik). Volume lalu lintas harian yang padat pada Jalan Cokroaminoto tentunya mengakibatkan peningkatan pencemaran udara Kota Denpasar. Kondisi udara yang tercemar mampu menyebabkan beberapa masalah kesehatan, diantaranya yaitu gangguan pernafasan seperti ISPA (infeksi saluran pernafasan akut), penyakit kulit, cepat lupa, pusing, dan cepat marah. Salah satu upaya yang bisa dilakukan untuk mengatasi masalah pencemaran udara adalah dengan penggalakan penanaman vegetasi pada jaringan jalan.

\subsection{Konsep Dasar}

Konsep dasar dirumuskan berdasarkan potensi dan permasalahan yang terjadi di tapak penelitian yaitu jarak lokasi penelitian dengan pusat Kota Denpasar yang cukup dekat berpotensi untuk menjadikan jalur hijau sebagai identitas Kota Denpasar, tanaman yang ada saat ini tidak cocok digunakan sebagai tanaman jalan, gulma yang tumbuh dengan subur karena jalur hijau tidak dirawat dengan baik, jalur tanaman gersang, jalur tanaman ditutup dengan perkerasan, jalur tanaman yang dijadikan tempat pembuangan sampah, dan volume lalu lintas harian pada Jalan Cokroaminoto yang padat memungkinkan terjadi peningkatan pencemaran udara. Berdasarkan potensi dan masalah tersebut, konsep dasar yang digunakan adalah lansekap jalan dengan tanaman fungsional. Fungsi tanaman yang diharapkan adalah fungsi tanaman sebagai penyerap polusi, kebisingan, identitas kota, dan peneduh pada ruas jalan arteri Cokroaminoto dan ruas jalan kolektor Gunung 
Agung serta fungsi tanaman sebagai penyerap polusi, kebisingan, dan identitas kota pada jalan lokal Serma Made Pil.

\subsection{Konsep Pengembangan}

\subsubsection{Konsep Ruang}

Konsep ruang pada tapak penelitian disesuaikan dengan kondisi sekitar areal jalan yang menurut peta rencana pola ruang wilayah Kota Denpasar pada Jalan Cokroaminoto terdiri dari area perdagangan dan jasa, pendidikan, kesehatan, dan terminal. Pada jalan Gunung Agung terdiri dari area perdagangan dan jasa serta pendidikan. Pada Jalan Serma Made Pil terdiri dari area perdagangan dan jasa serta pendidikan (Gambar 1).

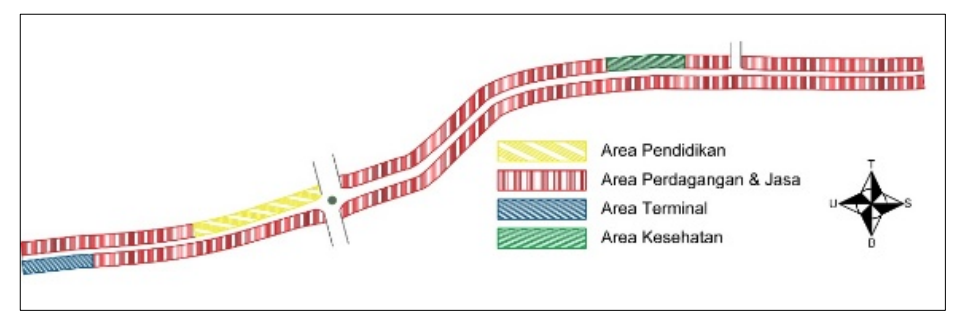

a. Konsep Ruang Jalan Arteri Cokroaminoto

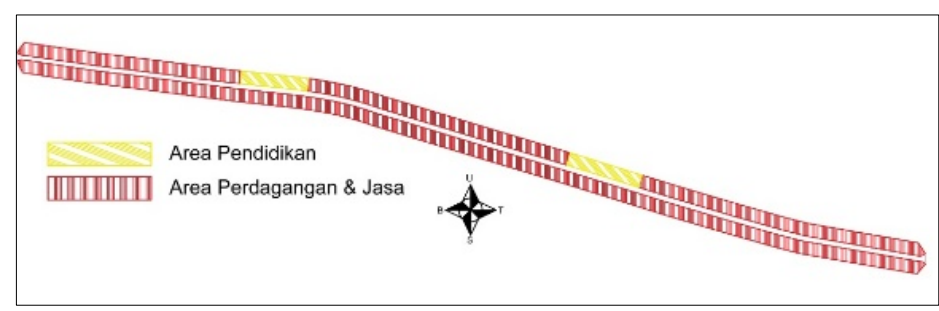

b. Konsep Ruang Jalan Kolektor Gunung Agung

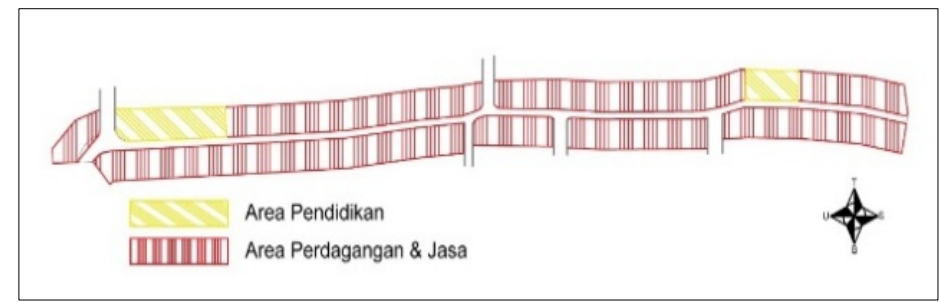

c. Konsep Ruang Jalan Lokal Serma Made Pil

\subsubsection{Konsep Tata Hijau}

Gambar 1. Konsep Ruang Tapak Penelitian

Gambar 2 merupakan gambar konsep tata hijau, dimana konsep tata hijau yang dikembangkan adalah tata hijau dengan penggunaan tanaman dengan fungsi tanaman yang disesuaikan dengan kondisi sekitar jalan. Pada Jalan Cokroaminoto dan Jalan Gunung Agung konsep tata hijau terdiri dari tata hijau dengan fungsi tanaman sebagai penyerap polusi, kebisingan, identitas, dan peneduh. Sementara pada Jalan Serma Made Pil konsep tata hijau terdiri dari konsep tata hijau dengan fungsi tanaman sebagai penyerap polusi, kebisingan, dan identitas. 


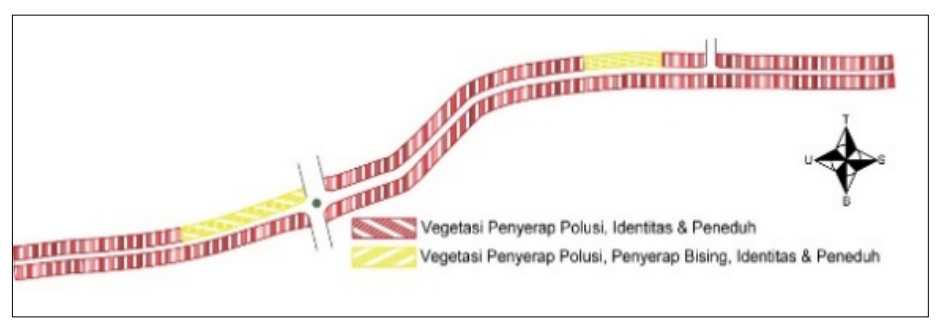

a. Konsep Tata Hljau Jalan Arteri Cokroaminoto

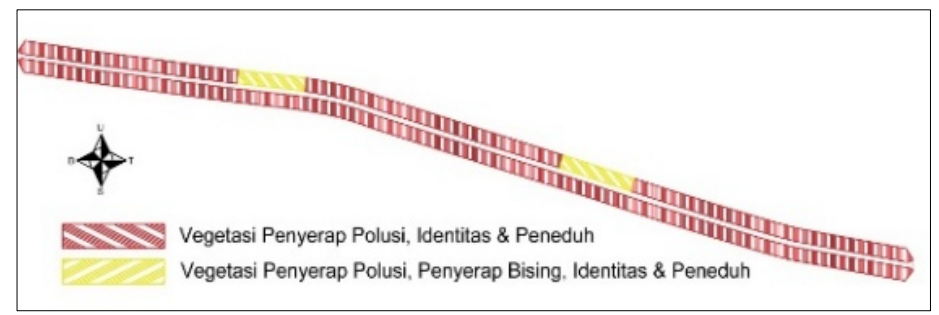

b. Konsep Tata Hijau Jalan Kolektor Gunung Agung

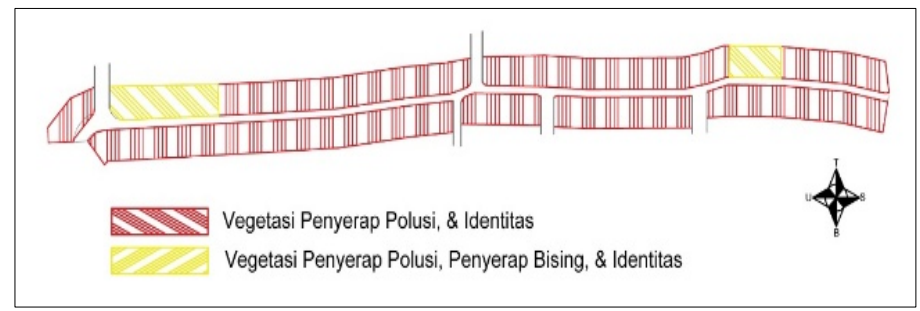

c. Konsep Tata Hijau Jalan Lokal Serma Made Pil

Gambar 2. Konsep Tata Hijau Tapak Penelitian

\subsection{Perencanaan}

Tahap perencanaan menghasilkan site plan yang merupakan hasil overlay dari konsep ruang dan konsep tata hijau (Gambar 4). Penataan tanaman pada masing-masing jalan berbeda tergantung dari kecepatan tempuh minimal yang diperbolehkan melintas pada masing-masing jalan. Haris dan Dines (1988) menjelaskan bahwa waktu yang diperlukan manusia untuk mengenali suatu rangsangan yang diterima melalui mata, telinga, maupun indra lain yang memerlukan penelaahan di otak adalah 1,47 detik sehingga pengulangan komposisi tanaman pada jalan arteri dengan kecepatan tempuh minimal $60 \mathrm{~km} / \mathrm{j}$ adalah $25 \mathrm{~m}$, jalan kolektor dengan kecepatan tempuh minimal $40 \mathrm{~km} / \mathrm{j}$ adalah $16 \mathrm{~m}$, dan untuk jalan lokal dengan kecepatan tempu minimal $20 \mathrm{~km} / \mathrm{j}$ adalah $8 \mathrm{~m}$. Mengingat terkerasan (beton) sudah terjadi maka penempatan pohon hanya dilakukan di area-are yang saat ini sudah tersedia planter box dengan lebar minimal $1.5 \mathrm{~m}$ seperti pada gambar 3.

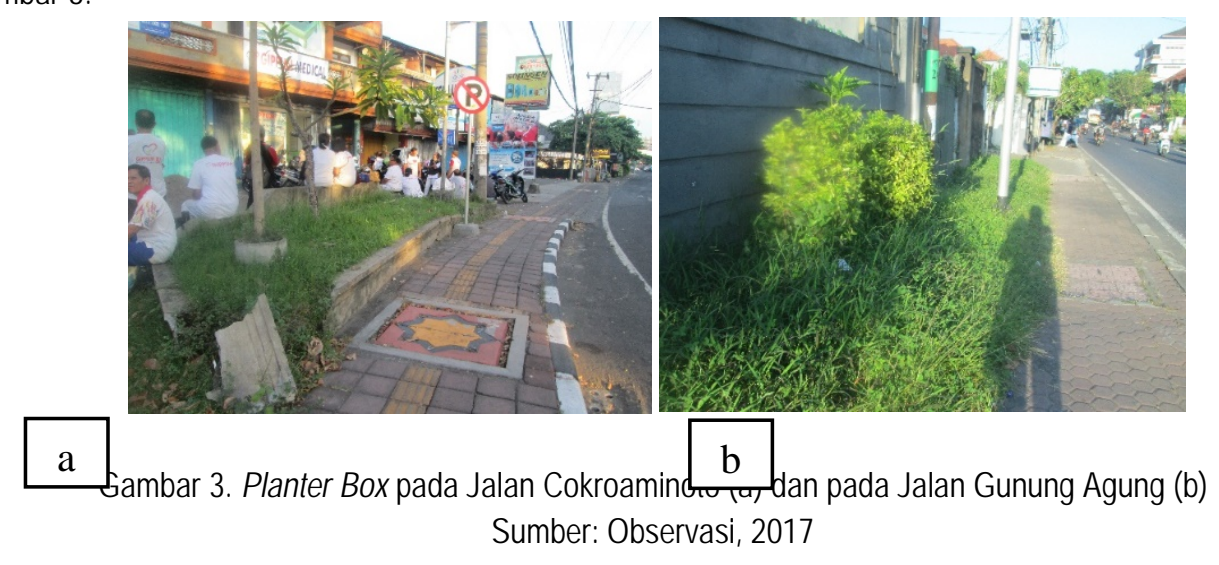


Gambar 4 merupakan rencana tapak dari masing-masing kelas jalan. Pada tapak pertama dan kedua yaitu untuk kelas jalan arteri dan jalan kolektor, disepanjang sisi jalan direncanakan menggunakan kombinasi vegetasi jenis pohon, perdu dan semak, Sedangkan untuk kelas jalan lokal, hanya menggunakan vegetasi jenis perdu dan semak saja.

a. Site Plan Jalan Arteri Cokroaminoto

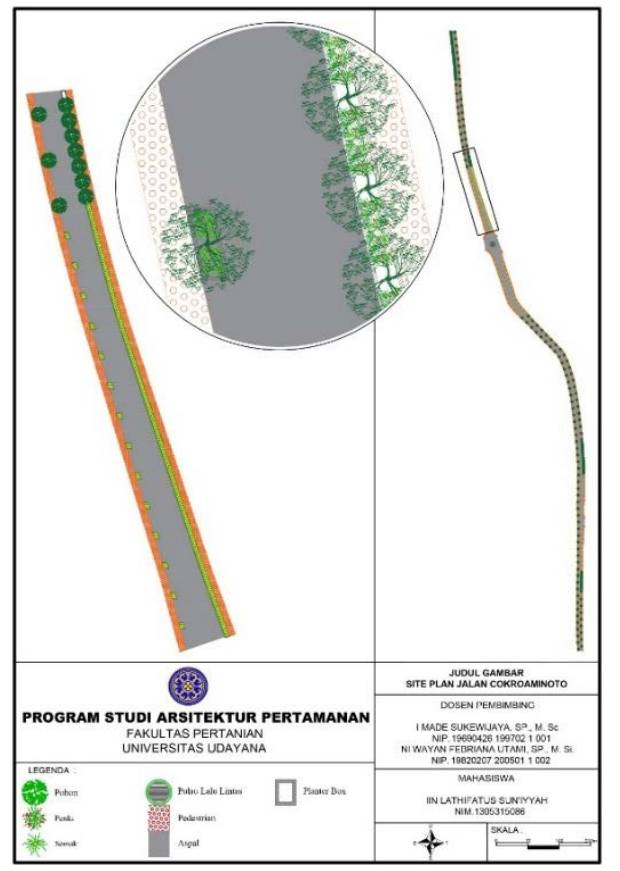

\section{b. Site Plan Jalan Kolektor Gunung Agung}

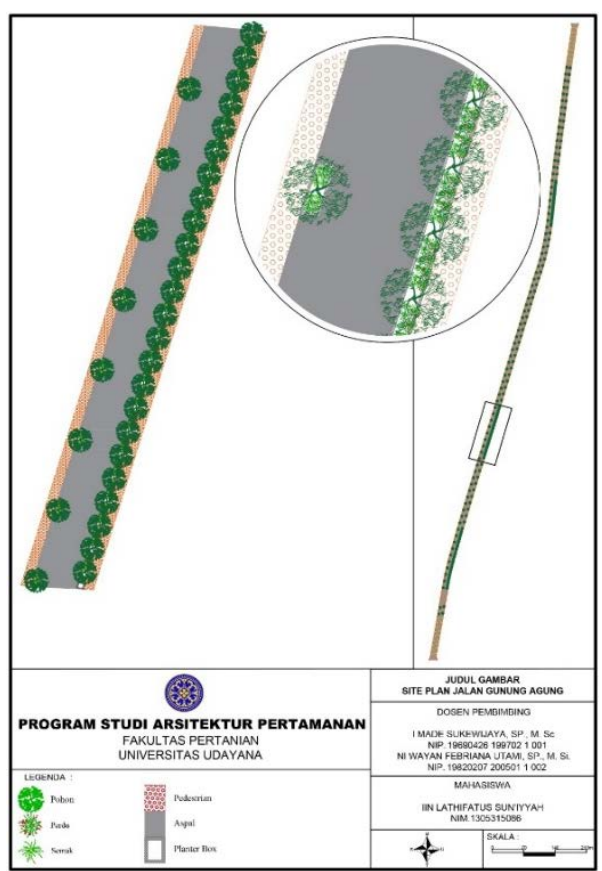

c. Site Plan Jalan Lokal Serma Made Pil

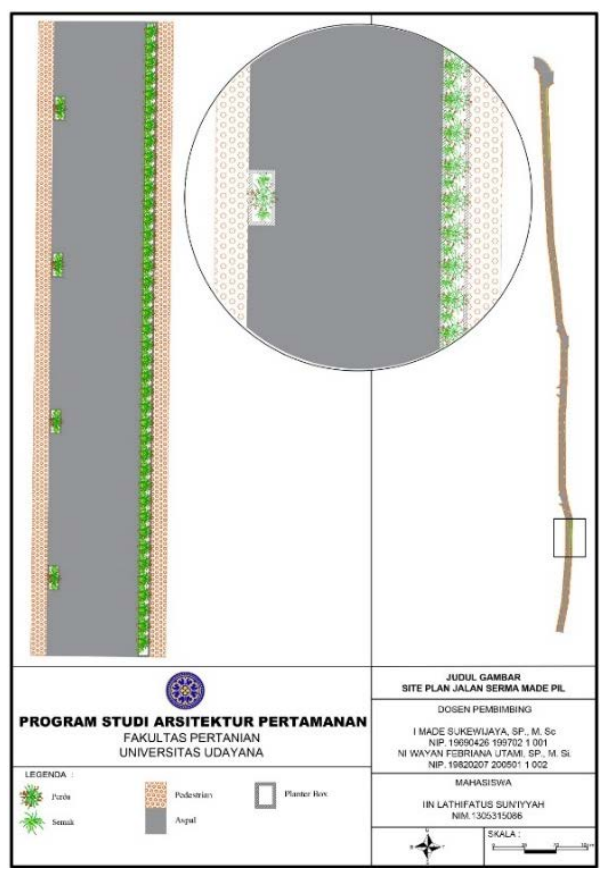

Gambar 4. Site Plan pada Tapak Penelitian 
Penanaman tanaman jenis pohon pada area pertokoan di Jalan Cokroaminoto dan Jalan Gunung Agung adalah $15 \mathrm{~m}$, penanaman pohon dengan jarak tersebut dimaksudkan untuk tidak menghalangi pandangan ke bangunan atau objek perdagangan. Sementara pada Jalan Serma Made Pil jarak penanaman tanaman pada area pertokoan adalah $10 \mathrm{~m}$, jarak penanaman tersebut bertujuan agar tidak menghalangi pandangan pada area perdagangan. Gambar 5 merupakan gambar potongan melintang dari Jalan Cokroaminoto, Jalan Gunung Agung, dan Jalan Serma Made Pil.

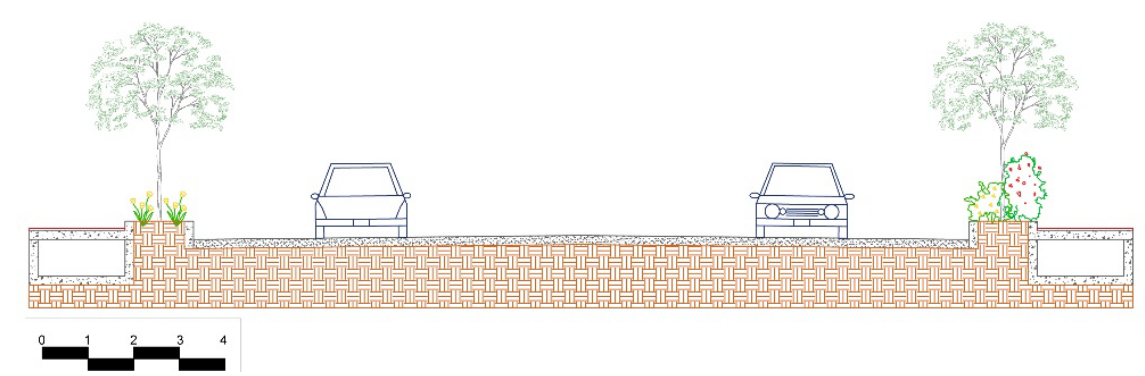

a. Potongan Melintang Jalan Arteri Cokroaminoto

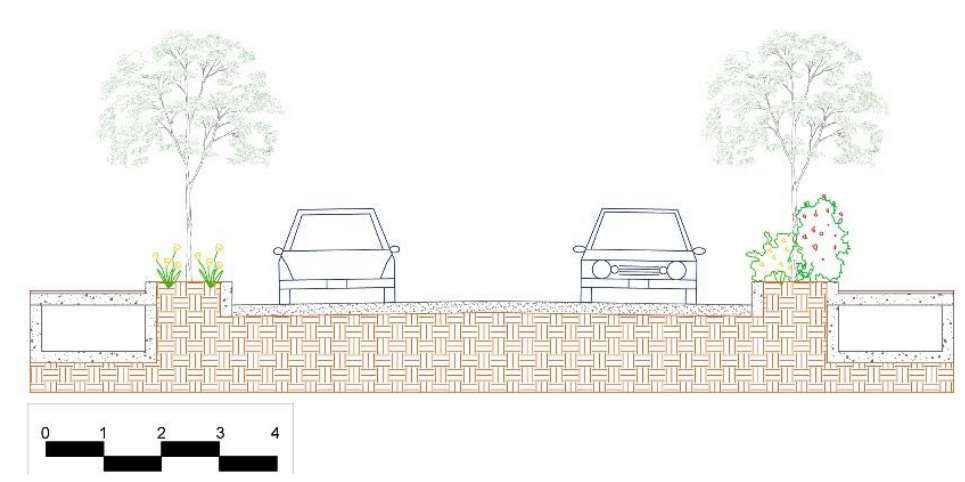

b. Potongan Melintang Jalan Kolektor Gunung Agung

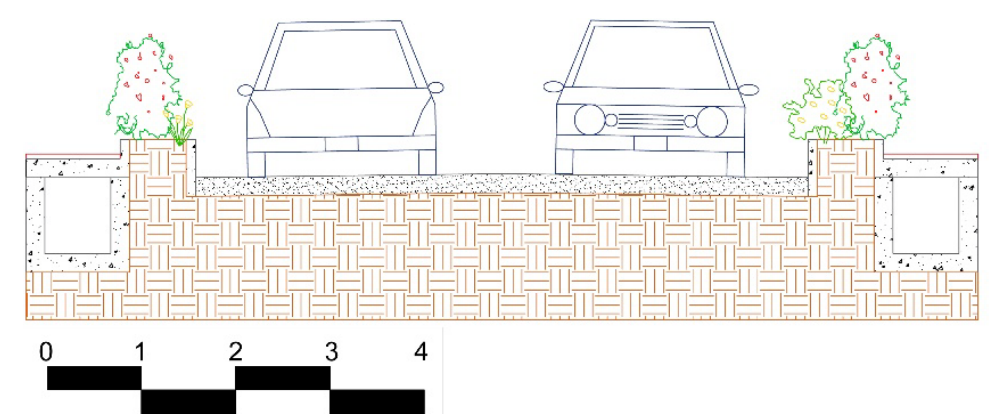

c. Potongan Melintang Jalan Lokal Serma Made Pil

Gambar 5. Potongan Melintang Pada Jalan Arteri (a), Kolektor (b) dan Lokal (c).

\section{Simpulan dan Saran}

\subsection{Simpulan}

Jarak lokasi penelitian dengan titik nol Kota Denpasar cukup dekat sehingga bisa dikembangkan sebagai identitas kota. Secara umum kondisi topografi tapak penelitian cenderung datar dan lurus. Ditemukan 
136 jenis tanaman pada tapak penelitian dengan permasalahan pada jalur penanaman yaitu tidak dirawat dengan baik sehingga gulma tumbuh dengan subur, gersang, tertutup perkerasan, serta terbengkalai. Volume lalu lintas pada Jalan Cokroaminoto tergolong padat. Konsep dasar yang digunakan dalam penelitian perencanaan lansekap jalan berdasarkan fungsi jalan adalah lansekap jalan dengan tanaman fungsional dengan fungsi tanaman sebagai penyerap polusi, kebisingan, identitas, dan peneduh pada jalan arteri Cokroaminoto dan jalan kolektor Gunung Agung serta fungsi tanaman sebagai penyerap polusi, kebisingan, dan identitas pada jalan lokal Serma Made Pil. Konsep pengembangan terdiri dari konsep ruang dan konsep tata hijau.

\subsection{Saran}

Penelitian ini hanya membahas tentang perencanaan tata hijau jalan, karena perlu adanya penelitian lebih lanjut mengenai perencanaan tata hijau jalan Kota Denpasar yang membahas tentang penempatan elemen lansekap jalan sesuai dengan regulasi yang ada.

\section{Daftar Pustaka}

Badan Pusat Statistik. 2007. Denpasar dalam Angka 2007. BPS Kota Denpasar. Denpasar . 2008. Denpasar dalam Angka 2008. BPS Kota Denpasar. Denpasar 2009. Denpasar dalam Angka 2009. BPS Kota Denpasar. Denpasar 2010. Denpasar dalam Angka 2010. BPS Kota Denpasar. Denpasar 2011. Denpasar dalam Angka 2011. BPS Kota Denpasar. Denpasar 2012. Denpasar dalam Angka 2012. BPS Kota Denpasar. Denpasar 2013. Denpasar dalam Angka 2013. BPS Kota Denpasar. Denpasar 2014. Denpasar dalam Angka 2014. BPS Kota Denpasar. Denpasar 2015. Denpasar dalam Angka 2015. BPS Kota Denpasar. Denpasar 2016. Denpasar dalam Angka 2016. BPS Kota Denpasar. Denpasar

Bararatin, K. dan Hayati, A. 2016. Penataan Jalur Hijau di Surabaya Berdasarkan Karakteristik Jalan dan Kemampuan Visual Pengamat Studi Kasus: Jalan Mastrip Surabaya. Emara Indonesian Jurnal of Arsitecture, 2(1): 1-12

Dinas Pekerjaan Umum Kota Denpasar. 2015. Rekapitulasi Daftar Jaringan Jalan Kota Denpasar Menurut Jenis Permukaan dan Kondisi Jalan Tahun 2015. Dinas Pekerjaan Umum Kota Denpasar. Denpasar

Dinas Perhubungan Kota Denpasar. 2015. Volume Lalu Lintas Jaringan Jalan Kota Denpasar. Dinas Perhubungan Kota Denpasar. Denpasar

Direktorat Bina Jalan Kota. 1997. Manual Kapasitas Jalan Indonesia (MKJI). Direktorat Bina Jalan Kota. Jakarta

Direktorat Jenderal Bina Marga.1996. Tata Cara Perencanaan Teknik Lansekap Jalan No. 033/T/BM/1996. Direktorat Jenderal Bina Marga Departemen Pekerjaan Umum. Jakarta

Harris, CW. and Dines, NT. 1988. Time-Saver Standards for Landscape Architecture. McGraw-Hill. United States of America

Iman. 2016. Kajian Efektifitas Model Jalur Hijau Untuk Mengurangi Kebisingan dalam Skala Laboratorium. S.P. Skripsi (tidak dipublikasikan). Institut Pertanian Bogor

Norma, M. P., N. G. Astawa, dan N. W. F. Utami. 2013. Perancangan Taman Terapi Hortikultura bagi Penderita Gangguan Jiwa pada Rumah Sakit Jiwa Provinsi Bali. E-Jurnal Agroekoteknologi Tropika, 2(4): 233243

Pemerintah Daerah Kota Denpasar. 2015. Rencana Kerja Pembangunan Daerah Kota Denpasar Tahun 2015. Pemerintah Daerah Kota Denpasar. Denpasar

Walidaen, M. B. 2017. Perencanaan Taman Islam pada Lansekap Islamic Center Provinsi Nusa Tenggara Barat. S.Arsl. Skripsi (Tidak dipublikasikan). Universitas Udayana Bali 